\title{
CURRENT SCENARIO OF SMEAR-POSITIVE LEPROSY CASES IN A RURAL TERTIARY CARE HOSPITAL IN NANDYAL, ANDHRA PRADESH
}

\author{
Syeda Mariam Seher1, Sanikommu Sreedevi², Gls. Sumanth³, Jinka Balakrishna ${ }^{4}$, Satta Naga Sireesha5, Mogalapu Anand Satya Tej 6 \\ ${ }_{1}^{1}$ Postgraduate Student, Department of Microbiology, Santhiram Medical College \& General Hospital, Nandyal, Andhra Pradesh. \\ 2 Professor \& HOD, Department of Microbiology, Santhiram Medical College \& General Hospital, Nandyal, Andhra Pradesh. \\ ${ }^{3}$ Assistant Professor, Department of Microbiology, Santhiram Medical College \& General Hospital, Nandyal, Andhra Pradesh. \\ ${ }^{4}$ Assistant Professor, Department of Microbiology, Santhiram Medical College \& General Hospital, Nandyal, Andhra Pradesh. \\ 5Tutor, Department of Microbiology, Santhiram Medical College \& General Hospital, Nandyal, Andhra Pradesh. \\ ${ }_{6}^{6}$ Postgraduate Student, Department of Microbiology, Santhiram Medical College \& General Hospital, Nandyal, Andhra Pradesh.
}

\section{ABSTRACT}

\section{BACKGROUND}

Leprosy is a chronic infectious disease caused by Mycobacterium leprae mainly affecting the skin, peripheral nerves. Leprosy has been officially eliminated from India since December 2005, still wide variations in prevalence rates continue to exist across the states and regions in the country.

Aims and Objectives- The Purpose of the study is to determine the prevalence of smear-positive leprosy cases in post-elimination era in a rural tertiary care hospital in Nandyal, Andhra Pradesh.

\section{MATERIALS AND METHODS}

This is a retrospective record based study conducted over a period of 2 years from September 2014 to August 2016. Patients with clinical suspicion of leprosy were referred to the Department of Microbiology, Santhiram Medical College \& Hospital where cases were confirmed by slit-skin smear examination.

\section{RESULTS}

Out of 83 clinically suspected cases (Male: Female ratio 1.67:1), 21 were diagnosed as smear positive for AFB of whom 12 (57.14\%) were male \& 9 (42.85\%) were female. Maximum number of cases (61.90\%) belonged to age group 21-40 years. $23.80 \%$ belonged to age group 41-60 years \& $14.28 \%$ to 61-80 years. Most of the smear-positive cases had bacteriological indices lying between $1+$ to $4+$, with a majority of patients (28.57\%) having BI of $1+$. Globi (BI 6+) were seen in $4.76 \%$ of patients. Morphological indices varied from $10 \%$ to $60 \%$. A decline in number of smear-positive cases was observed from $26.19 \%$ in 2014 to $24.39 \%$ in 2015.

\section{CONCLUSION}

The study shows that despite statistical elimination, leprosy is still in vogue. There is an urgent need to take up measures to keep a check on leprosy by timely surveillance, easy availability of multidrug therapy at all medical centres in India so that prompt treatment can be started to prevent damage to the nerves and prevent disabilities. Since transmission of leprosy is from man to man, the only way to achieve elimination is early diagnosis and treatment.

\section{KEYWORDS}

Leprosy, Smear-positive cases, AFB.

HOW TO CITE THIS ARTICLE: Seher SM, Sreedevi S, Sumanth G, et al. Current scenario of smear-positive leprosy cases in a rural tertiary care hospital in Nandyal, Andhra Pradesh. J. Evolution Med. Dent. Sci. 2017;6(34):2849-2851, DOI: $10.14260 /$ Jemds/2017/612

\section{BACKGROUND}

Leprosy or Hansen's disease is a bacterial disease of great antiquity having been recognised from Vedic times in India \& from biblical times in Middle East. Caused by Mycobacterium leprae, it is a chronic infectious disease which can affect all ages and both sexes. Norwegian physician named Gerhard Armauer Hansen discovered the bacterium in 1873.

Financial or Other, Competing Interest: None.

Submission 01-03-2017, Peer Review 13-04-2017,

Acceptance 19-04-2017, Published 27-04-2017.

Corresponding Author:

Dr. Syeda Mariam Seher,

H. No. 45/24-k-64-2-2,

Ameen Abbas Nagar,

Venkata Ramana Colony,

Kurnool-518003,

Andhra Pradesh.

E-mail: mariamseher@gmail.com

DOI: $10.14260 /$ jemds $/ 2017 / 612$
Mycobacterium leprae is a Gram positive, acid fast bacilli, aerobic and thermolabile, varying in size from $6-8 \mu \mathrm{m} \times 0.5$ $\mu \mathrm{m}$. It divides slowly, the generation time being $12-14$ days. It is characterised by a very long incubation period, $5-7$ years. It primarily affects the skin \& peripheral nerves, but has a wide range of clinical manifestations depending on the immune status of the patient. 1,2

Based on clinical manifestations, leprosy is classified as tuberculoid leprosy, lepromatous leprosy, indeterminate leprosy, borderline tuberculoid and borderline lepromatous leprosy. ${ }^{3}$ According to WHO, leprosy is divided into two groups paucibacillary and multibacillary. ${ }^{2}$ Lepra bacilli are demonstrated in smears as acid fast bacilli present either singly, small bundles or as globi. ${ }^{1}$ It requires $10^{4}$ bacilli/g of tissue for reliable detection in the smears. ${ }^{4}$ Demonstration of acid fast lepra bacilli in stained smears is a practical approach to confirm the diagnosis, monitor the progress of disease, 
treatment outcome and for calculating the bacteriological and morphological indices. ${ }^{1}$

Leprosy has been a major public health problem in India in the last century. National Leprosy Control Programme (NLCP) was launched in 1955 based on dapsone monotherapy. Then in 1983, National Leprosy Eradication Programme (NLEP) was introduced with the goal to decrease the prevalence rate of leprosy below 1 case/10,000 population which was achieved in December 2005 $(0.95 / 10,000$ population $) .{ }^{1}$ The prevalence rate was further reduced to $0.69 / 10,000$ population in March 20155. Leprosy was supposed to be eliminated globally by the year 2000.6 About $59 \%$ of the new leprosy cases detected globally in 2014-2015 were from India. ${ }^{7}$ According to the recent NLEP report of 2015-2016, about 1, 27,334 new cases were detected, with prevalence rate of $0.66 / 10000$ population in March 2016. ${ }^{8}$ Since transmission of leprosy is from man to man, the only way to achieve elimination is early diagnosis and treatment. 1

\section{Aims and Objectives}

The purpose of the study is to determine the prevalence of smear-positive leprosy cases in a tertiary hospital in Nandyal from September 2014 to August 2016.

\section{MATERIALS AND METHODS}

The Department of Microbiology, Santhiram Medical College \& General Hospital is a tertiary care centre providing laboratory confirmation of leprosy by slit-skin smear examination. This is a retrospective record based study conducted over a period of 2 years commencing from September 2014 to August 2016. All the patients suspected of leprosy, visiting or referred to this tertiary care centre were included in this study irrespective of their age \& sex. Smears were prepared from 2 sites (both ear lobes) for each patient. For collection of material from the ear lobes, slit and scrape method was used. The smears were stained with modified Ziehl-Neelsen stain and examined under oil immersion to look for acid fast bacilli, both intra and extracellular, and reported as positive or negative for AFB. Bacteriological indices were calculated.

\section{Bacteriological Index (BI)}

Density of lepra bacilli in smears including both solid and fragmented/granular forms, BI is obtained by adding up the index from each site examined and dividing by the total by number of sites examined.

\section{According to Ridley's Logarithmic Scale, Ranges of BI are}

- 1+: 1-10 bacilli/100 fields.

- 2+: 1-10 bacilli/10 fields.

- 3+: 1-10 bacilli/one field.

- 4+: 10-100 bacilli/one field.

- 5+: 100-1000 bacilli/one field.

- 6+: > 1000 bacilli/one field.

\section{RESULTS}

A total of 83 clinically suspected patients were examined. Males outnumbered the females. 52 were male and 31 were female. (Male: Female ratio 1.67:1). 21 patients were diagnosed as smear positive for acid fast bacilli if whom 12 $(57.14 \%)$ were male and $9(42.85 \%)$ were female (Table 1$)$.
Age-wise analysis of data shows that majority of patients belonged to the age group 21-40 years. The number of smearpositive cases also being highest in the same age group (Table 2).

Comparison of bacteriological indices among smearpositive cases shows that majority of the smear-positive cases had BI of $1+(28.57 \%)$. Smear-positive cases with globi (BI 6+) are 4.76\% (Table 3).

Year-wise analysis of data shows a decline in number of smear-positive cases was observed from $26.19 \%$ in 2014 to $24.39 \%$ in 2015 (Table 4).

\begin{tabular}{|c|c|c|}
\hline Gender & Total Cases & Smear-positive cases \\
\hline Male & 52 & 12 \\
\hline Female & 31 & 9 \\
\hline Total & $\mathbf{8 3}$ & $\mathbf{2 1}$ \\
\hline \multicolumn{2}{|c|}{ Table 1. Sex Distribution of Smear-positive } \\
Leprosy Cases \\
\hline
\end{tabular}

\begin{tabular}{|c|c|c|}
\hline Age Group & Number of Cases & Smear-positive cases \\
\hline $0-20$ & 2 & 0 \\
\hline $21-40$ & 40 & 13 \\
\hline $41-60$ & 31 & 5 \\
\hline $61-80$ & 10 & 3 \\
\hline \multicolumn{2}{|c|}{ Table 2. Age Wise Analysis of Smear-positive } \\
Leprosy Cases \\
\hline
\end{tabular}

\begin{tabular}{|c|c|c|c|c|}
\hline $\begin{array}{c}\text { Bacteriological } \\
\text { Index (BI) }\end{array}$ & Males & Females & Total & $\begin{array}{c}\text { Percentage } \\
\text { (\%) }\end{array}$ \\
\hline $1+$ & 4 & 2 & 6 & 28.57 \\
\hline $2+$ & 1 & 3 & 4 & 19.04 \\
\hline $3+$ & 3 & 2 & 5 & 23.80 \\
\hline $4+$ & 3 & 2 & 5 & 23.80 \\
\hline $5+$ & 0 & 0 & 0 & 0 \\
\hline $6+$ & 1 & 0 & 1 & 4.76 \\
\hline \multicolumn{6}{|c|}{ Table 3. Comparison of Bacteriological } \\
Indices among Smear-positive Leprosy Cases \\
\hline
\end{tabular}

\begin{tabular}{|c|c|c|c|}
\hline Year & $\begin{array}{c}\text { Number of } \\
\text { Patients } \\
\text { Examined }\end{array}$ & \begin{tabular}{|c|} 
Number of \\
Smear Positive \\
Patients
\end{tabular} & $\begin{array}{c}\text { Percentage of } \\
\begin{array}{c}\text { Smear Positive } \\
\text { Patients }\end{array}\end{array}$ \\
\hline $\begin{array}{c}\text { September } \\
2014 \text { To } \\
\text { August } 2015\end{array}$ & 42 & 11 & $26.19 \%$ \\
\hline $\begin{array}{c}\text { September } \\
2015 \text { To } \\
\text { August } 2016\end{array}$ & 41 & 10 & $24.39 \%$ \\
\hline Total & 83 & 21 & $25.30 \%$ \\
\hline
\end{tabular}

\section{DISCUSSION}

In our study, males were more affected than females, which is in concordance with trends prevalent in our country where males frequently self-report for treatment. Increased mobility and frequent interaction with community leads to increased opportunity for contacts in males. ${ }^{9}$ This is similar to findings reported by Stuti Kansra et al \& Singh AL et al ${ }^{1,10}$ Majority of the patients belonged to age group 21-40 years, which correlates with findings reported by Jindal et al \& Mathan 
et al 11,12 The bacteriological indices of smear positive patients ranged from $1+$ to $4+$ with majority of the patients $(28.57 \%)$ having BI of 1+indicating low bacillary load and good prognosis on treatment. But patients with BI $6+(4.76 \%)$, having high bacillary load \& disabilities are highly infectious and major cause of concern as they are more likely to transmit the disease among their contacts. Though there is a decline in the number of smear-positive cases from $26.19 \%$ in 2014 to $24.39 \%$ in 2015 , the difference is not much significant suggesting poor control of transmission of leprosy. Leprosy is a chronic granulomatous disease of humans with patients being the only source of infection. Bacteriological examination is an essential screening procedure for all patients in whom leprosy is suspected. Demonstration of Hansen's bacilli is considered important for diagnosis, classification and management of leprosy. A positive slit-skin smear is not only the third cardinal sign of leprosy but also confirms the diagnosis of leprosy. ${ }^{4}$ Though the specificity of slit-skin smears is almost $100 \%$ as it directly demonstrates the presence of Hansen's bacilli, the sensitivity is low ranging from $10 \%-50 \%{ }^{4} \quad$ Histological examination BIG (Bacteriological index of granuloma in biopsies) has many advantages and the yield of acid fast bacilli in tissue sections are reported to be better with sensitivity higher than that of slit-skin smear. In a study carried out by Bhushan et al, the difference between the sensitivities of BI in slit-skin smears and BIG in biopsies were statistically analysed and the difference was highly significant. ${ }^{13}$

Directorate General of Health Services, Central Leprosy Division, New Delhi has issued guidelines on strengthening of skin smear labs for leprosy control activities and programs. However, continuous supervision and monitoring for the collection and processing of slit-skin smears are necessary especially at referral centres in order to ensure uniformity, reliability and high levels of quality and performance standards. Announcing elimination of leprosy as a public health problem in India under NLEP was probably an ambitious aspiration. However, such a strategy cannot be justified scientifically at the moment in view of new case detection rate not abating significantly. In such a scenario, the importance of slit-skin smear examination should not be undervalued in spite of all the drawbacks. 4 Despite the various advances in the field of leprosy management, it is still referred as a "living death".5

\section{Limitations}

This was a retrospective data analysis based on departmental records, hence bias in reporting cannot be ruled out. We included only the patients presenting to our department either voluntarily or on being referred. Community based surveys covering the district population could be more informative. Smears were collected only from 2 sites (2 earlobes) and not from eight sites. Moreover, the patients who were smear negative for Hansen's bacilli cannot be excluded as disease free, because of the limitations of reporting the bacilli in the smears.

\section{CONCLUSION}

The experience from our study suggests that despite statistical elimination, leprosy is still in vogue. We may have won the battle, but the war is still on and lot of work needs to be done.

There is an urgent need to take up measures to keep a check on leprosy by timely surveillance, easy availability of diagnostic tests and multidrug therapy (MDT) at all medical centres in India so that prompt treatment can be started to prevent damage to the nerves and prevent disabilities. ${ }^{1}$ Large numbers of new cases have been detected in recent years because of adaption of new strategy "Modified Leprosy Elimination Campaign (MLEC)" and effective health education campaign. ${ }^{10}$ The most important factor that could have significant impact on prevalence is the coverage of entire population with adequate multidrug therapy (MDT). ${ }^{10}$

New cutting-edge diagnostic tools are not going to be available for bedside use anytime soon. Slit-skin smear is still the most useful diagnostic method available. ${ }^{4}$ Since transmission of leprosy is from man to man, the only way to achieve elimination is early diagnosis and treatment.

\section{REFERENCES}

[1] Stuti K, Pushpa Devi. Raising burden of smear-positive leprosy cases in tertiary care hospital of North India. International J of Scientific Research 2015;4(9):388-9.

[2] Sagar V. Prevalence of leprosy "A five year study" in a tertiary care hospital in Ludhiana. International J of Physical and Applied Sciences 2015;2(7):1-4.

[3] Ridley DS, Jopling WH. Classification of leprosy according to immunity. A five-group system. Int J Lepr Other Mycobact Dis 1966;34(3):255-73.

[4] Mahajan VK. Slit-skin smear in leprosy: lest we forget it ! Indian J Lepr 2013;85(4):177-83.

[5] Hegde SP, Shenoy MM, Pinto M, et al. Leprosy: chronicles of a disabling disease. Arch Med \& Health Sci 2015;3(2):346-9.

[6] Jain A. Current status of leprosy in a tertiary care hospital in north India. Indian J Med Res 2012;135(3): 439-40.

[7] Ardeshna KP, Someshwar S, Rohatgi S, et al. Leprosy Scenario at a tertiary-level hospital in Navi Mumbai: a four-year retrospective study. MGM J Med Sci 2016;3(2):72-6.

[8] NLEP--Progress report for the year 2015-2016. 2016.

[9] Chhabra N, Grover C, Singal A, et al. Leprosy scenario at a tertiary level hospital in Delhi: a 5-year retrospective study. Indian J Dermatol 2015;60(1): 55-9.

[10] Singh AL, Vagha SJ, Agarwal A, et al. Current scenario of leprosy at tertiary care level hospital of rural central India. Indian J Dermatol Venereol Leprol 2009;75(5):520-2.

[11] Jindal N, Shanker V, Tegta GR, et al. Clinicoepidemiological trends of leprosy in Himachal Pradesh: a five year study. Indian J Lepr 2009;81(4): 173-9.

[12] Mathan R, Devan KM. Incidence and clinical profile of leprosy in a tertiary care hospital: a retrospective study. International $\mathrm{J}$ of Scientific Study 2016;4(3):178-9.

[13] Bhushan P, Sardana K, Koranne RV, et al. Diagnosing multibacillary leprosy: a comparative evaluation of diagnostic accuracy of slit-skin smear, bacterial index of granuloma and WHO operational classification. Indian J Dermatol Venereol Leprol 2008;74(4):322-6. 